\title{
Genetic Polymorphism in the Promoter and 5' UTR of HSP-70 Gene in Three Strains of Indigenous Tswana Chickens and Commercial Broilers
}

\author{
James Buttie Machete $^{1 *}$, Patrick Monametsi Kgwatalala ${ }^{1}$, Goitseone Malambane ${ }^{2}$, Shalaulani James Nsoso ${ }^{1}$, \\ and John Cassius Moreki ${ }^{1}$ \\ ${ }^{\prime}$ Botswana University of Agriculture and Natural Resources, Faculty of Animal and Veterinary Sciences, Department of Animal Sciences, \\ Private bag 0027, Gaborone, Botswana \\ ${ }^{2}$ Botswana University of Agriculture and Natural Resources, Faculty of Agriculture, Department of Crop and Soil Sciences, \\ Private Bag 0027, Gaborone, Botswana \\ *Corresponding author's Email: buttiemachete@ gmail.com; ORCID 0000-0001-6457-3092
}

Received: 18 October 2021

Accepted: 10 December 2021

\begin{abstract}
The current study was conducted to investigate sequence polymorphisms in the promoter, 5 'untranslated regions (UTR), and partial exon regions of chicken HSP-70 gene in the normal $(n=24)$, naked neck $(n=22)$, and dwarf $(n=$ 12) strains of indigenous Tswana chickens relative to the commercial broiler chickens $(n=20)$. Genomic DNA extracted from the whole blood of the three strains of indigenous Tswana chickens and the commercial broilers were amplified using PCR and sequenced. The PCR amplicons comprised a 210 bp promoter region, a 112 bp 5'UTR, and a 463 bp partial exon of the chicken HSP-70 gene. Multiple sequence alignments of the partial sequences of chicken HSP-70 gene in indigenous Tswana chickens and the commercial broilers revealed no polymorphisms in the promoter region, two SNPs in the 5'UTR (A303G and G309A) and another two SNPs (G427 and A628G) in the partial exon sequence of chicken HSP-70 gene. The SNP G427A was unique to the normal strain and the other three SNPs were common to all the four chicken strains studied. The identified four SNPs linked up in individual chickens resulted in a total of seven different haplotypes in the studied four chicken populations. A total of seven different haplotypes were found in indigenous Tswana chickens and only two haplotypes were found in the commercial broilers. More nucleotide (4SNPs vs 3 SNPs) and more haplotype diversity (7 haplotypes vs 2) were thus found in indigenous Tswana chickens, compared to the commercial broilers in the partial sequence of HSP-70 gene.
\end{abstract}

Keywords: HSP-70 gene, Indigenous Tswana chicken, Polymorphism, Sequencing, SNPs

\section{INTRODUCTION}

Chickens do not have sweat glands, and thus, body heat dissipation to the environment is not easy and in most cases, chickens are prone to heat stress (Tamzil, 2014; Aryani et al., 2019; Afsal et al., 2021). When the ambient temperature goes beyond the comfort zone of $>28^{\circ} \mathrm{C}$, then heat stress can crop up anytime in both egg-laying and broiler chickens (Aryani et al., 2019). In chickens, heat stress causes high temperatures that can negatively affect growth and egg quality (Oberheitmann, 2013), and cause decreased feed intake, eggshell quality, egg production, body weight gains, and even death in domestic chickens during summertime (Cahaner et al., 2008; Melesse et al., 2011; Aryani et al., 2019). Cellular mechanisms used to alleviate heat stress in animals may include changes in the functions of cells, including transcription, translation, and protein synthesis (Negri et al., 2013). One of the adaptive mechanisms to increased environmental temperatures in chickens includes the production of heat shock proteins (HSPs) which play an important role in the protection and repair of cells and tissues exposed to high environmental temperatures (Chen et al., 2016). The HSP-70 is one of the heat shock proteins produced by animals in response to extreme heat conditions and it plays an important role in heat tolerance (Zuiderweg et al., 2013).

In chickens, the HSP-70 protein is encoded by the HSP-70 gene which is found in chicken autosome 5 and comprises a single exon, the upstream Promoter and 5 UTR and downstream 3' UTR (Morimoto et al., 1986). According to GenBank: AY143693.1, the entire chicken HSP-70 gene comprises 2594 bp and encodes a protein of 653 amino acids (Junprung et al., 2019). The promoter comprises $210 \mathrm{bp}$, the 5UTR comprises $112 \mathrm{bp}$ and the 
3 UTR comprises 309 bp. According to Najafi et al. (2018), a total of 35 SNPs have been found in chicken HSP-70 with 25 SNPs occurring in the protein-coding region and the rest in the regulatory regions (Promoter, 5 UTR, and 3'UTR). Most of the studies on chicken HSP70 gene polymorphism concentrated on the exon or protein-coding region because of its direct effect on the amino acids sequence of the resulting protein (alleles of a gene) (Gan et al., 2015; Najafi et al., 2018). Only a few studies investigated polymorphisms in regulatory regions of the chicken HSP-70 gene. Polymorphisms in the regulatory region of the gene are, however, very important because they influence gene expression (Öner et al., 2017). According to Silver and Noble (2011), pre-transcriptional activation of HSP-70 gene has been thoroughly reviewed while its downstream regulation by 5 UTR and 3 UTR has received less attention. The 5 UTR regions of genes are useful in controlling mRNA expression levels and stability (Basiricó et al., 2011; Sodhi et al., 2013; Öner et al., 2017). The control of translation initiation is mainly under the responsibility of $5^{\prime}$ UTRs and gene expression can therefore be influenced by SNPs in the regulatory regions (Araujo et al., 2012; Haimov et al., 2015). Indigenous chickens are known to be more thermotolerant to heat stress compared to exotic chickens (Duanginda et al., 2017). It is, therefore, hypothesized that the differences in thermotolerance between indigenous Tswana chickens and exotic chickens could be due to sequence variations in the promoter and 5 UTR regions of the chicken HSP-70 gene.

The objectives of the current study were to investigate polymorphism in the promoter and 5 UTR regions of chicken HSP-70 gene in normal, naked neck and dwarf strains of Tswana chickens, compared to the commercial broiler chickens.

\section{MATERIALS AND METHODS}

\section{Ethical approval}

The keeping of the research birds was approved by the Animal Research Ethics Committee of Botswana University of Agriculture and Natural Resources (Approval No.2020-13), which conforms to the guidelines and the use of research animals.

\section{Experimental animals}

Blood samples were collected from a total of 24 normal, 22 naked necks, and 12 dwarf strains of indigenous Tswana chickens. The sampling locations of different strains of Tswana chickens (Table 1). Additional 20 blood samples were collected from Ross broiler chickens at Notwane farm located in Gaborone. The blood samples were collected from the medial metatarsal vein located on the leg of a chicken better suited for puncture using a 23-gauge, 1-in needle. The alternative site for blood collection was the brachial vein on the wings. All blood samples were collected into vacutainer tubes containing EDTA and kept on ice in the field and later stored in the freezer at $-20^{\circ} \mathrm{C}$ until DNA extraction.

Table 1. Locations of indigenous Tswana chickens and the number of samples per location in Kweneng and Southern districts of Botswana

\begin{tabular}{llccc}
\hline \multirow{2}{*}{$\begin{array}{l}\text { Sampling } \\
\text { location }\end{array}$} & \multirow{2}{*}{ District } & \multicolumn{3}{c}{ Number of samples per location } \\
\cline { 3 - 5 } & & Normal & Naked neck & Dwarf \\
\hline Sojwe & Kweneng & 4 & 3 & 5 \\
Kaudwane & Kweneng & 1 & 1 & 0 \\
Maboane & Kweneng & 2 & 2 & 2 \\
Malwelwe & Kweneng & 3 & 3 & 2 \\
Kweneng & Kweneng & 2 & 2 & 1 \\
Keng & Southern & 3 & 1 & 0 \\
Seherelela & Southern & 3 & 2 & 1 \\
Thankane & Southern & 2 & 4 & 0 \\
Lerolwane & Southern & 2 & 3 & 0 \\
Magotshwane & Southern & 2 & 1 & 1 \\
Total & & 24 & 22 & 12 \\
\hline
\end{tabular}

\section{DNA isolation}

Total genomic DNA was extracted from avian blood using QIAGEN DNeasy tissue and blood Kit, California, USA, following the manufacturer's protocol (Qiagen, 2003). Briefly, $200 \mu 1$ of digestion buffer and $20 \mu 1$ of proteinase $\mathrm{K}$ were added to $5 \mu \mathrm{l}$ of whole blood. The mixture was vortexed for 15 minutes and then incubated in a water bath at $50^{\circ} \mathrm{C}$ for 10 minutes. Then, $200 \mu 1$ of cold $100 \%$ ethanol was added to each sample and mixed by vortexing for 15 seconds. The resulting mixture was transferred into a spin column placed inside a collecting tube and centrifuged at $8000 \times \mathrm{g}$ for 1 minute. Tubes containing the flow-through were discarded and the spin column was then transferred to new collecting tubes. In the next step, $500 \mu 1$ of the first washing buffer was added to each spin column and centrifuged at $1000 \times \mathrm{g}$ for 1 minute. Again, the collection tubes containing flowthrough were discarded and the spin columns were transferred to new collection tubes. Afterward, $500 \mu \mathrm{l}$ of second washing buffer were added to the spin column and then centrifuged at $14000 \times \mathrm{g}$ for 3 minutes. Following centrifugation, spin columns were transferred to clean microcentrifuge tubes. Then, $150 \mu \mathrm{l}$ of elution buffer was added to the spin columns and incubated at room temperature for 5 minutes. Following the incubation, the microcentrifuge tubes holding the spin columns were centrifuged at $8000 \times \mathrm{g}$ for 1 minute to elute the DNA. 


\section{DNA quantification}

The quantity and quality of extracted DNA were established using a NanoDrop 2000/2000c Spectrophotometer. DNA quality was established by measuring absorbance at 260/280.

\section{PCR amplification and DNA Sequencing}

PCR amplifications were performed with a programmable thermal cycler, PTC-100 ${ }^{\mathrm{TM}}$ (MJ-Research, Inc., Watertown, MA, USA) in a final reaction volume of $50 \mathrm{ng}$ of genomic DNA, $0.2 \mathrm{mM}$ dNTPs, $1.5 \mathrm{mM}, \mathrm{MgCl}_{2}$, $0.6 \mu \mathrm{M}$ of each primer and 1.5 units Taq DNA polymerase. After an initial denaturation step of $94^{\circ} \mathrm{C}$ for 3 minutes, the reaction mixture was subjected to 34 cycles at $94^{\circ} \mathrm{C}$ for 45 seconds, $54^{\circ} \mathrm{C}$ for 30 seconds, and $72^{\circ} \mathrm{C}$ for 1 minute and 30 seconds, plus a final extension step of $72^{\circ} \mathrm{C}$ for 10 minutes. Amplification was confirmed by running the PCR products on $2 \%$ agarose gels and visualizing them under ultraviolet rays (Vallone et al., 2008). PCR products were then shipped to Inqaba BiotecAfrica`s Genomics Company, Pretoria, South Africa for sequencing. At Inqaba Biotec PCR amplicons were purified using The PureLink PCR purification kit of Thermo Fisher Scientific, South Africa following the manufacturer's protocol (Vallone et al., 2008). DNA sequences were generated using $\mathrm{ABI}$ V3.1 Big dye terminator cycle sequencing kit (Applied Biosystems, Foster City, CA, USA) and the thermocycler GeneAmp PCR system 9700 (Applied Biosystems, Foster City, CA, USA). Sequences were generated with both forward and reverse primers (Table 2) and read on ABI3500XL DNA analyzer (Applied Biosystems, Foster City, USA).

Table 2. Primers used on PCR amplification of the chicken 5 UTR of HSP-70 gene

\begin{tabular}{llc}
\hline $\begin{array}{l}\text { Primer's } \\
\text { name }\end{array}$ & Sequence & $\begin{array}{c}\text { Position on } \\
\text { the reference } \\
\text { sequence }\end{array}$ \\
\hline HSP-70-F1 & 5' GAGTGGCGCAGCGTAGAAAG '3 & 18 \\
\hline HSP-70-F2 & 5' GATTGGTCCTTAGCGTTCTGGC '3 & 208 \\
\hline HSP-70-R1 & 5' TTCCTCTTGGTCAGTCAGCC '3 & 382 \\
\hline HSP-70-R3b & 5' CTGGGAGTCGTTGAAGTAAGCG '3 & 856 \\
\hline
\end{tabular}

The letters $\mathrm{F}$ and $\mathrm{R}$ in primer names refer to their orientation (forward and reverse, respectively). Source: Mazzi et al. (2003).

\section{Sequence analysis}

Chromatographs developed from sequencing were processed using ApE, A Plasmid Editor version 2.0.53, (Jorgensen.biology.utah.edu) to verify the sequences and SNPs in the amplified regions of the chicken HSP-70 gene. Furthermore, samples and reference sequences were aligned using the Clustal $\mathrm{W}$ multiple sequence alignment program (Simmonds, 2012) to establish the presence of SNPs in the amplified regions (Brocchieri et al., 2008). Nucleotide substitutions at the identified SNP loci were identified from chromatographs generated by the program Chromas Lite (https://technelysium.com.au/wp/). Translation of DNA sequences into protein sequences was done online using the Nucleotide Amino Acid Derived Visualization (NADV) (Abascal et al., 2010).

\section{Statistical analysis}

Potential functional motifs in the sequenced promoter region of chicken HSP-70 gene in the three strains of indigenous Tswana chicken and commercial broiler were identified using Proscan software (http.//wwwbimass.cit.nih.gov/molbio/proscan/). Allele and genotype frequencies at the identified SNP loci were calculated using Gene Pop program (v 1.2) (Raymond and Rousset, 1995; Lachance, 2008). Haplotypes in the partial sequence of the chicken HSP-70 gene were determined by clustal X ( $\mathrm{v}$ 1.81) and MEGA (v 4.0) (Tamura et al., 2007). Observed heterozygosity $\left(\mathrm{H}_{\mathrm{o}}\right)$ and expected heterozygosity $\left(\mathrm{H}_{\mathrm{e}}\right)$ were estimated using FSTAT (v.2.9.3.2) (Goudet, 2002).

\section{RESULTS AND DISCUSSION}

\section{Amplified regions of chicken HSP-70 gene}

The two primer pairs used in the sequencing of the chicken HSP-70 gene in the study resulted in a $200 \mathrm{bp}$ promoter region, $112 \mathrm{bp} \mathrm{5} 5^{\prime}$ UTR, and $453 \mathrm{bp}$ fragment of the chickens' HSP-70 gene coding region. The study thus sequenced a 775 bp fragment of the chickens' HSP-70 gene in different strains of indigenous Tswana chickens and the commercial broiler chickens.

\section{Functional motifs in the partial sequence of chicken HSP-70 gene}

Functional motifs found in the regulatory regions (Promoter and 5' UTR) of chicken HSP-70 gene in indigenous Tswana chickens and commercial broiler chickens included CAAT box, specificity protein 1 (SP1), heat shock element (HSE2), and heat shock element 1(HSE1) and a TATA box (Figure 1). All these motifs were previously reported by Aryani et al. (2019) in four different strains of indigenous Indonesian chickens. According to Morimoto et al. (1986) the chicken HSP-70 gene shares $73 \%$ and $80 \%$ sequence homology with Drosophila and human HSP-70 genes respectively, 
including common features such as TATA box, CAAT box, SP1, HSE1, and HSE2 in the promoter region. Heat shock elements in the promoter region are a common feature of both mammalian and plant HSP-70 gene. According to Zhao et al. (2020) sequence variations in heat shock elements, the position of the heat shock elements within the promoter and the molecular architecture of the heat shock elements may be responsible for the varying affinity in the Heat shock factors-Heat shock elements interaction which ultimately influences transcription rate of HSP-70 gene and consequently the magnitude of the heat shock response.

\section{SNPs in the partial sequence of chicken HSP-70 gene}

SNPs found in the partial sequence of chicken HSP70 gene in normal, naked neck and dwarf strains of indigenous Tswana chickens (Table 3) and depicted in Figures 1-5. There were no SNPs in the promoter region of chicken HSP-70 gene in normal, naked neck and dwarf strains of indigenous Tswana chickens as well as in the commercial broiler chickens. According to (Öner et al., 2017), SNPs in the promoter region of cattle may have a negative effect on pregnancy, calving rate, spermatogenesis, and embryonic mortality. The monomorphism of the promoter region of the HSP-70 gene in different strains of indigenous Tswana chickens and the commercial broiler may, therefore, be meant to guard against the afore-mentioned negative effects of mutations in the Promoter of chicken HSP-70 gene. Two SNPs (A303G, G309A) were found in the 5'UTR and while the other two SNPs (G427A, A628G) were found in the partial exon sequence of the chicken HSP-70 gene. Gan et al. (2015) found 6 SNPs and 24 SNPS in the 5'UTR and coding region of chicken HSP-70 gene respectively, in Chinese indigenous chickens. More variation has been reported in the 5'UTR of bovine HSP70 gene with a total of 43 SNPs (Öner et al., 2017). The
A303G SNP in the 5'UTR was found in the three strains of indigenous Tswana chickens and the commercial broiler chickens while the G309A SNP was found only in normal and dwarf strains of Tswana chickens. An adenine nucleotide deletion at the $63^{\text {rd }}$ nucleotide (A63 del mutation) was only found in a single chicken of the dwarf strain within what appears like a CAAT box,

According to (Öner et al., 2017) untranslated regions of genes play an important role in terms of gene expression levels and mRNA stability. The 5'UTR controls expression levels of the transcript (Silver and Noble, 2011; Öner et al., 2017), and variations or mutations in the 5 UTR may therefore directly influence the HSP-70 protein expression levels which may result in phenotypic differences in performance. SNP G427A was unique to the normal strain of indigenous Tswana chickens and SNP A628G was found in the three strains of indigenous Tswana chickens and the commercial broiler chickens. More SNPs were thus found in the partial sequence of chicken HSP-70 in indigenous Tswana chickens than in commercial broiler chickens which is consistent with (Öner et al., 2017) who reported more variability in 5 UTR and 3 UTR regions of bovine HSP70 gene among native Turkish cattle breeds than the exotic Holstein breeds.

All the mutations found in the current study were transitional exchanges and the two SNPs in the coding region were silent (conservative) mutations that do not result in amino acids substitutions in the resulting protein. More transitional mutations $(\mathrm{A} / \mathrm{G}$ or $\mathrm{T} / \mathrm{C})$ and lack of transversional mutations (A/C or $\mathrm{T} / \mathrm{G}$ ) in the chicken HSP70 gene are consistent with those reported by Vignal et al. (2002) indicating more transitional mutations over transversion mutations in the study of human and mammalian genomes. According to Lamolle et al. (2006), silent mutations in the coding regions of most genes introduce genetic diversity while maintaining protein integrity and functionality.

Table 3. SNPs and the locations in HSP-70 gene sequence in three strains of indigenous Tswana chickens and commercial broiler chickens

\begin{tabular}{lllll}
\hline Strain & Nucleotide position** & Type & Change & Amino acid identity \\
\hline Normal, Naked neck, Dwarf and Broiler & 5UTR, 303 & Transition & $\mathrm{A} \rightarrow \mathrm{g}$ & \\
Normal and Dwarf & 5 UTR, 309 & Transition & $\mathrm{g} \rightarrow \mathrm{a}$ & \\
Normal & Exon, 427 & Transition & $\mathrm{g} \rightarrow \mathrm{a}$ & $\begin{array}{l}\text { Same, gtg } \rightarrow \text { gta } \\
\text { (valine } \rightarrow \text { valine })\end{array}$ \\
Normal, Naked neck, Dwarf and Broiler & Exon, 628 & Transition & $\mathrm{a} \rightarrow \mathrm{g}$ & $\begin{array}{l}\text { Same, tca } \rightarrow \text { tcg } \\
\text { (serine } \rightarrow \text { serine) }\end{array}$ \\
\hline
\end{tabular}

*Altered nucleotides and amino acids are shown in bold. **Nucleotides position is based on GenBank No. AY143693.1 
Ref : TGGCGCAGCGTAGAAAGCGAGACGGATCGAGAAAAAACAGGAAGAAGCCCGATCTGGCTG Nak:----------------------------CTRGAAACAGGGAGA-GCCCGATCTGGCTG Dwa: $:----------------------------A A A A M R G G G A G G A A G C C C G A T C T G G C T G$

\section{CAAT box}

Ref : CAATCTACGGGAGAGGGTTGGGCTAGAGAGTGGGCGCTACGCTTCTGATTGGGCAGGAGG Nak: CAATCTACGGGAGAGGGTTGGGCTAGAGAGTGGGCGCTACGCTTCTGATTGGGCAGGAGG Dwa :CA-TCTACGGGAGAGGGTTGGGCTAGAGAGTGGGCGCTTCCCTTCTGATTGGGCAGGAGG

\section{A63 del SP 1}

Ref : CAAG GGGCGGFCGCTCTTCGGCTAGTCCGGGAGGCGATTGGTCAACTGCGGCAGTCGGGT Nak: CAAGGGGCGGGCGCTCTTCGGCTAGTCCGGGAGGCGATTGGTCAACTGCGGCAGTCGGGT Dwa: CAAGGGGCGG GCGCTCTTCGGCTAGTCCGGGAGGCGATTGGTCAACTGCGGCAGTCGGGT

CAAT

HSE2 / HSE1

TATA box Ref : GTCTGG ATTC GT CCTTAGCGTTCTGGCAGGTTCCAGA AGAAGGCTAAGCGGACTATAAA G Nak: GTCTGGATTC GTCCTTAGCGTTCTGGCAGGTTCCAGA AGAAGGCTAAGCGGAC TATAAA G Dwa: GTCTGGATTC GTCCTTAGCGTTCTGGCAGGTTCCAGA AGAAGGCTAAGCGGAC IATAAA G Ref=reference sequence, Nak=naked neck; Dwa=dwarf

Ref: AGGGCGCGAGCGGCGCCGTAACGGCAGATCGCGCCGCAGACAGCAGCGAGAGCGGGCGGA Nak: AGGGCGCGAGCGGCGCCGTAACGGCAGATCGCGCCGCAGACAGCAGCGAGAGCGGGCGGA Dwa: AGGGCGCGAGCGGCGCCGTAACGGCAGATCGCGCCGCAGACAGCAGCGAGAGCGGGCGGA

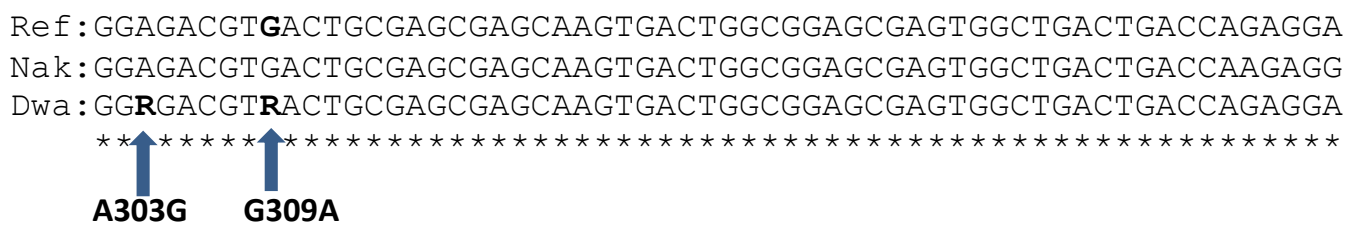

Ref: Reference sequence, Nak: Naked neck, Da: Dwarf

Figure 1. Functional motifs and SNP positions in the Promoter and 5'UTR of indigenous Tswana chicken HSP-70 gene

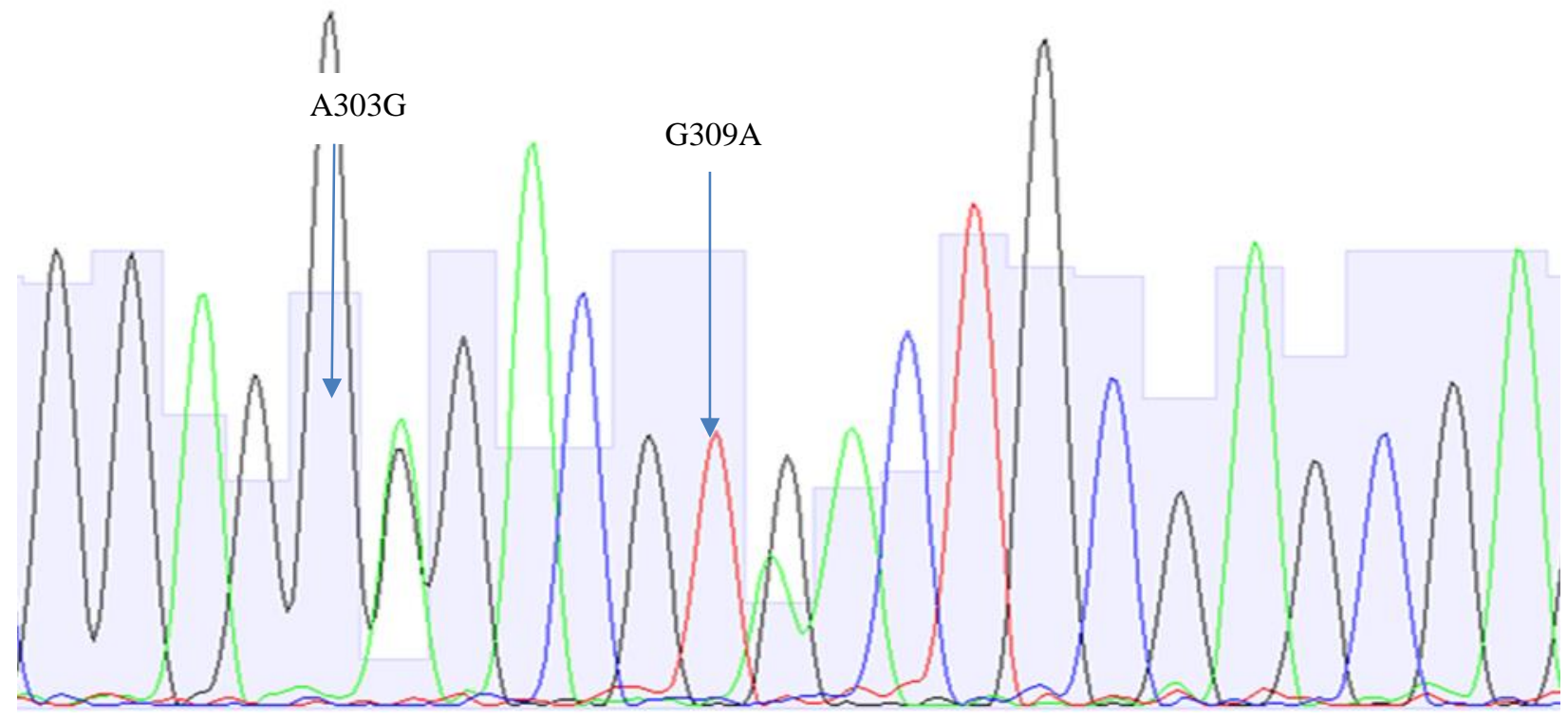

Figure 2. Sequence chromatograph showing SNPs in the 5'UTR of indigenous Tswana chicken HSP-70 gene 


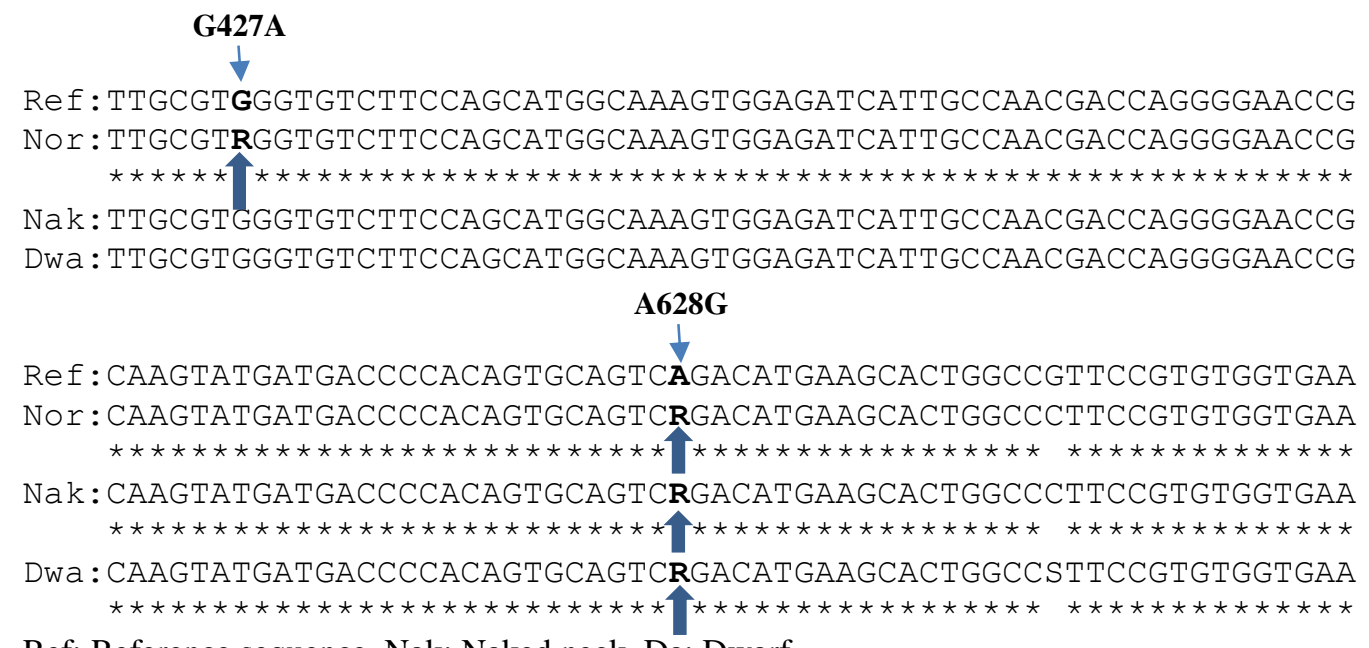

Ref: Reference sequence, Nak: Naked neck, Da: Dwarf

Figure 3. SNP positions in the Partial exon sequence of indigenous Tswana chicken HSP-70 gene

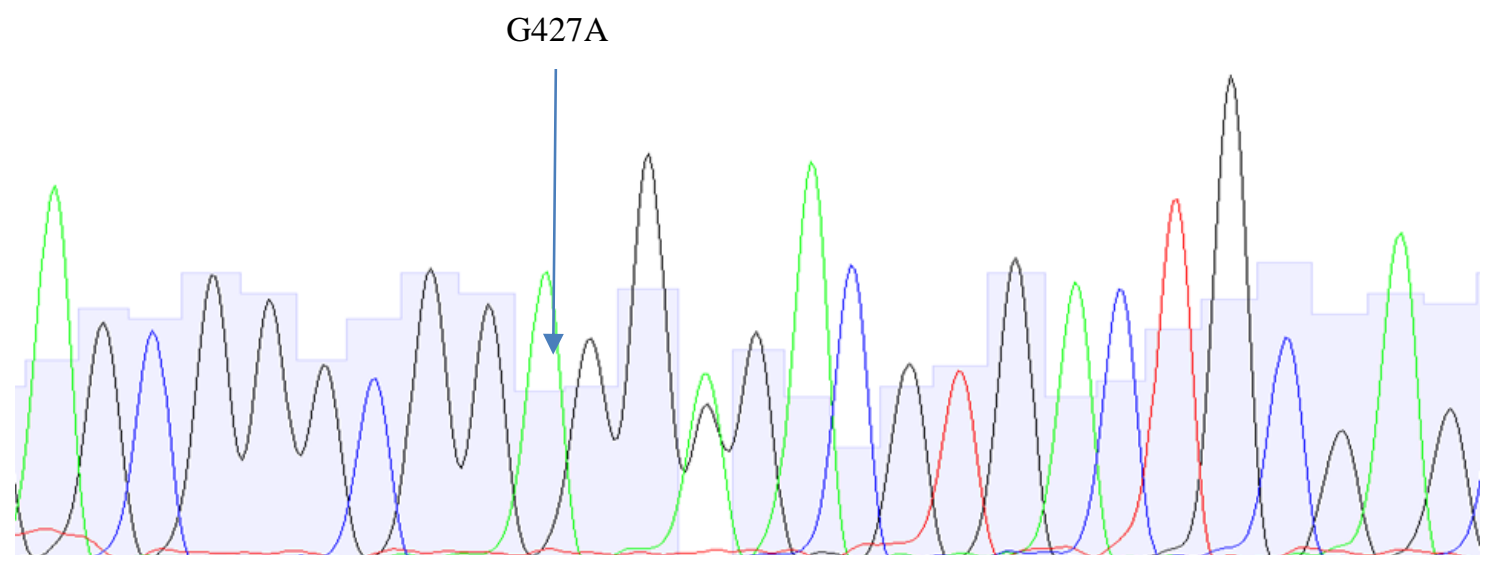

Figure 4. Sequence chromatograph showing the SNP in the partial exon sequence of indigenous Tswana chicken HSP-70 gene

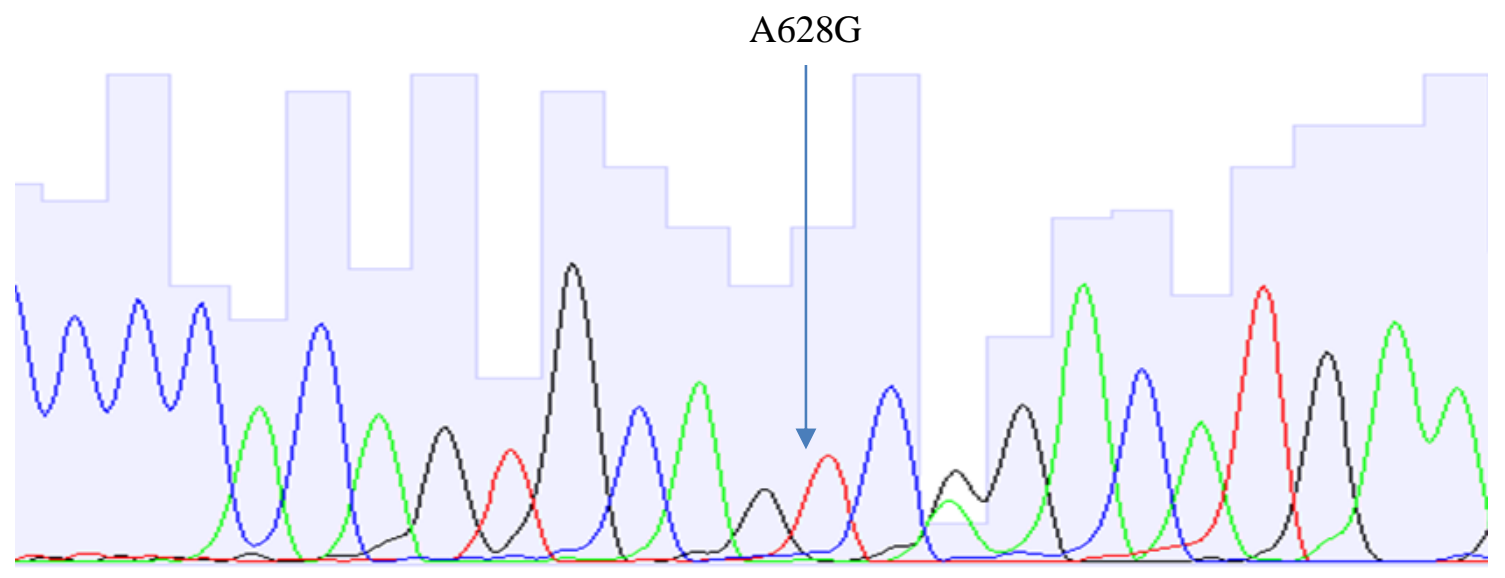

Figure 5. Sequence chromatograph showing the SNP in the partial exon sequence of indigenous Tswana chicken HSP-70 gene 


\section{Allele and genotype frequencies at the 5'UTR of chicken HSP70 gene}

Allele and genotype frequencies of the identified SNPs at 5 UTR of the chicken HSP-70 gene in different strains of Tswana chickens and the commercial broilers (Table 4). The A- allele at A303G locus was the most frequent in the normal, naked neck, and dwarf strains of indigenous Tswana chickens and the commercial broiler chickens. The G-allele was the least frequent at A303G locus in all the four strains of chickens under the study suggesting that the A-allele was the wild type. At the G309 locus, the G-allele occurred at the highest frequency in all the four strains of the investigated chickens (Table 4). The A-allele at G309A locus occurred at low frequencies in the normal and dwarf strains of indigenous Tswana chickens and was completely absent in the naked neck strain of indigenous Tswana chickens and the commercial broiler chickens suggesting that the A-allele is likely a new variant resulting from very recent mutation.
Allele and genotype frequencies of the identified SNPs in the partial sequence of the coding region of chicken HSP-70 gene in different strains of Tswana chickens and the commercial broiler (Table 4). The Aallele at G427A locus was the only one found in the normal strain of indigenous Tswana chickens and was completely absent in naked neck, dwarf, and commercial broiler chickens. The frequency of G-allele was higher than that of the A-allele at A628G in the normal strain of indigenous Tswana chickens. The A-allele occurred at a higher frequency than the G-allele in normal and dwarf strains of indigenous Tswana of chickens. The A-and Galleles at $\mathrm{A} 628 \mathrm{G}$ locus occurred at equal frequencies in commercial Ross broiler and the A-allele was completely absent in the naked neck strain of indigenous Tswana chickens. The naked neck strain was monomorphic for the G- allele at A628G locus resulting in 100\% frequency of the G-allele in the naked neck population of indigenous Tswana chickens.

Table 4. Genotype and allele frequencies across the strains of indigenous Tswana and commercial broiler chickens

\begin{tabular}{|c|c|c|c|c|c|c|c|c|}
\hline \multirow[b]{2}{*}{ Strains } & \multirow[b]{2}{*}{ Loci } & \multicolumn{2}{|c|}{ Allele frequency } & \multicolumn{3}{|c|}{ Genotype frequencies } & \multirow[b]{2}{*}{$\mathbf{H}_{\mathbf{0}}$} & \multirow[b]{2}{*}{$\mathbf{H}_{\mathrm{e}}$} \\
\hline & & $\mathbf{G}$ & $\mathbf{A}$ & GG & GA & $\mathbf{A A}$ & & \\
\hline \multirow{2}{*}{ Normal } & G309A & 0.96 & 0.04 & $22(0.92)$ & $2(0.08)$ & 0 & 0.08 & 0.08 \\
\hline & A628G & 0.37 & 0.63 & 0 & $18(0.75)$ & $6(0.25)$ & 0.75 & 0.47 \\
\hline \multirow[b]{2}{*}{ Naked neck } & A303G & 0.23 & 0.77 & 0 & $10(0.46)$ & $12(0.55)$ & 0.46 & 0.35 \\
\hline & G309A & 1.00 & 0 & $22(1.00)$ & 0 & 0 & 0 & 0.0 \\
\hline \multirow[t]{2}{*}{ Dwarf } & G309A & 0.93 & 0.07 & $12(0.86)$ & $2(0.14)$ & 0 & 0.14 & 0.13 \\
\hline & $\mathrm{A} 628 \mathrm{G}$ & 0.43 & 0.57 & 0 & $12(0.86)$ & $2(0.14)$ & 0.86 & 0.49 \\
\hline \multirow{3}{*}{ Broiler } & A303G & 0.05 & 0.95 & 0 & $2(0.10)$ & $18(0.90)$ & 0.10 & 0.10 \\
\hline & G309A & 1.00 & 0 & $20(1.00)$ & 0 & 0 & 0 & 0.0 \\
\hline & A628G & 0.50 & 0.50 & 0 & $20(1.00)$ & 0 & 0 & 0.5 \\
\hline
\end{tabular}

Genotype frequencies at $\mathrm{A} 303 \mathrm{G}$ and G309A loci in the 5'UTR of the chicken HSP-70 in different strains of indigenous Tswana and commercial broiler chickens (Table 4). The heterozygous GA genotype at the A303G locus of chicken HSP-70 gene was the most frequent (0.67) followed by homozygous AA genotype, and lastly the GG genotype in the normal strain of indigenous Tswana chickens. Homozygous AA genotype at A303G locus was, however, the most frequent followed by heterozygous GA in the naked neck and dwarf strains of indigenous Tswana chickens and the commercial broilers. The homozygous GG genotype at A303G locus was completely absent in sampled population of naked neck and dwarf strains of indigenous Tswana chickens and commercial broilers. The GG genotype at G309A locus was the most frequent, followed by the GA heterozygotes and lack of AA homozygotes in the sampled population of the normal strain of indigenous chickens. The naked neck strain of indigenous Tswana chickens and the commercial broilers were monomorphic at G309A locus resulting in $100 \%$ homozygous GG genotype at that locus. The GG genotype at G309A locus occurred at the highest frequency, followed by GA heterozygotes and lack of homozygous AA genotype in the dwarf strain of indigenous Tswana chickens. The small number of individuals of different strains of indigenous Tswana chickens and the commercial broilers sequenced in the current study might have contributed to absenteeism of some alleles and genotypes (Kgwatalala et al., 2012). The authors observed that selection (both artificial and natural) 
also has the potential to change both allele and genotype frequencies in the population (Buffalo and Coop, 2020).

The homozygous GG genotype at the G427A locus of chicken HSP-70 was the most frequent (0.83) and only found in the normal strain of indigenous Tswana chickens. Homozygous AA and heterozygous GA genotypes at G427A locus in the normal strain of indigenous chickens occurred at a similar frequency of 0.08 . The GG genotype at $\mathrm{A} 628 \mathrm{G}$ locus was the only genotype in the naked neck strain of indigenous Tswana chicken and was completely absent in the dwarf strains of Tswana chickens and the commercial broiler chicken. The heterozygous GA genotype at A628G locus occurred at a relatively higher frequency than the homozygous AA genotype in the dwarf strain of indigenous Tswana chicken and the commercial Ross broiler. All commercial broiler chickens were in fact heterozygous GA at A628G locus.

Genetic diversity measures (observed heterozygosity $\left[\mathrm{H}_{\mathrm{o}}\right]$ and expected heterozygosity $\left[\mathrm{H}_{\mathrm{e}}\right]$ ) at different SNP loci are presented in Table 4 . The highest genetic diversity (measured by $\mathrm{H}_{\mathrm{o}}$ ) was found at the A628G locus in the normal and dwarf strains at $\mathrm{A} 303 \mathrm{G}$ locus in the normal strain of indigenous Tswana chicken. Moderate genetic diversity was only found at $\mathrm{A} 303 \mathrm{G}$ locus in the naked neck strain of indigenous Tswana chicken. Low genetic diversity was found at G309A locus in the normal and dwarf strains of Tswana chickens and at G427A locus and at A628G locus in the normal and dwarf strains of Tswana chickens, respectively. There was no genetic diversity at G309A and A628G loci in the naked neck strain of Tswana chicken and commercial broiler. $\mathrm{H}_{\mathrm{o}}$ was generally higher than $\mathrm{H}_{\mathrm{e}}$ at $\mathrm{A} 303 \mathrm{G}$ locus all the four populations under study at A628G in the normal strain, and at G309A and A628G loci in the dwarf strain indicating an excess of heterozygous individuals in the general population and possibly lack of inbreeding at those loci.

\section{Haplotypes found in the partial sequence of chicken HSP70 gene}

The SNPs reported in Table 3 linked up in individual chickens to produce haplotypes in the partial sequence of the HSP-70 gene shown in Table 5. The haplotypes are characterized by nucleotides at SNP loci 303, 309, 427, and 628, respectively, with SNP loci numbering according to GenBank: AY143693.1. Seven unique haplotypes were found in the four-chicken population under the study. The H1 haplotype was the most frequent and common to naked neck, normal and dwarf strains of Tswana chickens and the commercial broilers. The $\mathrm{H} 2$ haplotype was found in the normal, naked neck and dwarf strains of Tswana chickens and was completely absent in the commercial broilers. The $\mathrm{H} 3, \mathrm{H} 4$, and $\mathrm{H} 5$ haplotypes were unique to the normal strain of indigenous Tswana chickens and the H6 haplotype was found only in the naked neck and dwarf strains of indigenous Tswana chickens. The H7 haplotype was found only in the dwarf strain of indigenous Tswana chickens. More haplotype diversity at the HSP-70 locus was thus found in indigenous Tswana chickens, compared to the commercial broiler chickens. This is not surprising as indigenous Tswana chickens have not been subjected to any form of artificial selection while the commercial broilers were subjected to intense selection during development, hence the low genetic diversity in commercial broiler chickens. The high diversity at the HSP-70 locus in indigenous Tswana chickens might also explain their heat tolerance compared to the commercial broilers.

Table 5. Haplotypes and their frequencies (5'UTR and coding region of chicken HSP-70 gene) of indigenous Tswana chicken strains and commercial broiler chickens

\begin{tabular}{|c|c|c|c|c|}
\hline Strains & Nucleotide's combinations & Haplotypes & Number & Frequencies \\
\hline \multirow{5}{*}{ Normal } & $\mathrm{A}_{303} \mathrm{G}_{309} \mathrm{G}_{427} \mathrm{~A}_{628}$ & H1 & 28 & 0.58 \\
\hline & $\mathrm{G}_{303} \mathrm{G}_{309} \mathrm{G}_{427} \mathrm{G}_{628}$ & $\mathrm{H} 2$ & 14 & 0.29 \\
\hline & $\mathrm{G}_{303} \mathrm{G}_{309} \mathrm{~A}_{427} \mathrm{G}_{628}$ & H3 & 2 & 0.04 \\
\hline & $\mathrm{G}_{303} \mathrm{G}_{309} \mathrm{~A}_{427} \mathrm{~A}_{628}$ & $\mathrm{H} 4$ & 2 & 0.04 \\
\hline & $\mathrm{G}_{303} \mathrm{~A}_{309} \mathrm{~A}_{427} \mathrm{G}_{628}$ & $\mathrm{H} 5$ & 2 & 0.04 \\
\hline \multirow{3}{*}{ Naked neck } & $\mathrm{A}_{303} \mathrm{G}_{309} \mathrm{G}_{427} \mathrm{~A}_{628}$ & H1 & 24 & 0.55 \\
\hline & $\mathrm{A}_{303} \mathrm{G}_{309} \mathrm{G}_{427} \mathrm{G}_{628}$ & H6 & 10 & 0.23 \\
\hline & $\mathrm{G}_{303} \mathrm{G}_{309} \mathrm{G}_{427} \mathrm{G}_{628}$ & $\mathrm{H} 2$ & 10 & 0.23 \\
\hline \multirow{4}{*}{ Dwarf } & $\mathrm{A}_{303} \mathrm{G}_{309} \mathrm{G}_{427} \mathrm{~A}_{628}$ & H1 & 14 & 0.50 \\
\hline & $\mathrm{A}_{303} \mathrm{G}_{309} \mathrm{G}_{427} \mathrm{G}_{628}$ & H6 & 10 & 0.36 \\
\hline & $\mathrm{G}_{303} \mathrm{G}_{309} \mathrm{G}_{427} \mathrm{G}_{628}$ & $\mathrm{H} 2$ & 2 & 0.07 \\
\hline & $\mathrm{G}_{303} \mathrm{~A}_{309} \mathrm{G}_{427} \mathrm{G}_{628}$ & H7 & 2 & 0.07 \\
\hline \multirow{2}{*}{ Broiler } & $\mathrm{A}_{303} \mathrm{G}_{309} \mathrm{G}_{427} \mathrm{~A}_{628}$ & H1 & 20 & 0.50 \\
\hline & $\mathrm{A}_{303} \mathrm{G}_{309} \mathrm{G}_{427} \mathrm{G}_{628}$ & H6 & 20 & 0.50 \\
\hline
\end{tabular}




\section{CONCLUSION}

There were no SNPs in the promoter region of the chicken HSP-70 gene. Two SNPs (A303G and G309A) were found in the 5UTR (A303G and G309A) and another two SNPs (G427 and A628G) were found in the partial exon sequence of the chicken HSP-70 gene. The SNP (G427A) was unique to the normal strain of indigenous Tswana chicken and the other three SNPs were common to all the four chicken strains studied. The identified four SNPs linked up in individual chickens led to a total of seven different haplotypes in the studied four chicken populations. A total of seven different haplotypes were found in indigenous Tswana chickens and only two haplotypes were found in the commercial broilers.

\section{DECLARATION}

\section{Acknowledgments}

The authors would like to thank the Botswana University of Agriculture and Natural Resources for funding the study. The authors would also like to thank Inqaba Biotec, Pretoria, South Africa, for availing all their sequencing equipment and for assisting with the sequencing of the HSP-70 gene.

\section{Competing interests}

The authors declare that they have no known competing financial interests or personal relationships that could have appeared to influence the work reported in this paper.

\section{Authors' contributions}

James Buttie Machete collected samples, designed, and performed the experimental works of this study. James Buttie Machete, Patrick Monametsi Kgwatalala, and Goitseone Malambane 1 performed the analysis, acquisition, and interpretation of data. James Buttie Machete drafted the manuscript. Patrick Monametsi Kgwatalal, John Cassius Moreki, and Shalaulani James Nsoso revised, edited the manuscript, and approved the final manuscript.

\section{Ethical considerations}

All authors approved the final draft of the manuscript for publication. Ethical issues (including plagiarism, consent to publish, misconduct, data fabrication and/or falsification, double publication and/or submission, and redundancy) have been checked by the authors.

\section{REFERENCES}

Abascal F, Zardoya R, and Telford MJ (2010). TranslatorX: Multiple alignment of nucleotide sequences guided by amino acid translations. Nucleic Acids Research, 38(2): 713. DOI: https://www.doi.org/10.1093/nar/gkq291

Afsal A, Bagath, M, Sejian V, Krishnan, G, Beena V, and Bhatta R (2021). Effect of heat stress on HSP70 gene expression pattern in different vital organs of Malabari goats. Biological Rhythm Research, 52: 380-394. DOI: https://www.doi.org/10.1080/09291016.2019.1600270

Araujo PR, Yoon K, Ko D, Smith AD, Qiao M, Suresh U, Burns SC, and Penalva LOF (2012). Before it gets started: Regulating translation at the 5'UTR. Comparative and Functional Genomics, Article ID: 475731. DOI: https://www.doi.org/10.1155/2012/475731

Aryani A, Solihinb DD, Sumantric C, Afnanc R, and Sartika T (2019). Genetic diversity of the structure of HSP70 gene in Kampung Unggul Balitbangtan (KUB), Walik, and Kate Walik chickens. Tropical Animal Science Journal, 42: 180188. Available at: https://garuda.ristekbrin.go.id/documents/detail/1224347

Basiricó L, Morera P, Primi V, Lacetera N, Nardone A, and Bernabucci U (2011). Cellular thermotolerance is associated with heat shock protein 70.1 genetic polymorphisms in Holstein lactating cows. Cell Stress Chaperones, 16: 441448. DOI: https://www.doi.org/10.1007/s12192-011-0257-7

Brocchieri L, Everly Conway de Macario EC, and Alberto JL (2008). HSP-70 genes in the human genome: Conservation and differentiation patterns predict a wide array of overlapping and specialized functions. BMC Evolutionary Biology, 8: 19. DOI: https://www.doi.org/10.1186/14712148-8-19

Buffalo V, and Coop G (2020). Estimating the genome-wide contribution of selection to temporal allele frequency change. Proceedings of the National Academy of Sciences of the United States of America (PNAS), 117: 20672-20680. Available at: https://www.pnas.org/content/pnas/117/34/20672.full.pdf

Cahaner A, Ajuh JA, Siegmund-Schultze M, and Azoulay Y (2008). Effects of the genetically reduced feather coverage in naked neck and featherless broilers on their performance under hot conditions. Poultry Science, 87: 2517-2527. DOI: http://www.dx.doi.org/10.3382/ps.2008-00284

Chen ZY, Zhang WW, Gan JK, Kong LN, Zhang XQ, Zhang DX, and Luo QB (2016). Genetic effect of an A/G polymorphism in the HSP70 gene on thermotolerance in chicken. Genetics and Molecular Research, 15: 15028271. DOI: https://www.doi.org/10.4238/gmr.15028271

Duangjinda M, Tunim S, Duangdaen C, Boonkum W (2017). Hsp70 Genotypes and heat tolerance of commercial and native chickens reared in hot and humid conditions. Brazilian Journal of Poultry Science, 19: 7-18. DOI: https://www.doi.org/10.1590/1806-9061-2016-0245

Gan JK, Jiang LY, Kong LN, Zhang XQ, and Luo QB (2015). Analysis of genetic diversity of the heat shock protein 70 gene on the basis of abundant sequence polymorphisms in chicken breeds. Genetics and Molecular Research, 14: $1538-1545$.

DOI:

https://www.doi.org/10.4238/2015.March.6

Goudet J (2002). FSTAT, a program to estimate and test gene diversities and fixation indices. (Version 2.9.3). Available at: https://www.scienceopen.com/document?vid=79097bb4ec3c-47c3-94a1-47085d721e6b

Haimov O, Sinvani H, and Dikstein R (2015). Cap-dependent, scanning-free translation initiation mechanisms. Biochimica 
et Biophysica Acta (BBA) - Gene Regulatory Mechanisms, 1849: 1313-1318. DOI: https://www.doi.org/10.1016/j.bbagrm.2015.09.006

Junprung W, Norouzitallab P, De Vos S, Tassanakajon A, Viet DN, Van-Stappen G, and Bossier P (2019). Sequence and expression analysis of HSP70 family genes in Artemia franciscana. Scientific Reports, 9: 8391. DOI: https://www.doi.org/10.1038/s41598-019-44884-y.I

Kgwatalala PM, Thutwa K, and Nsoso SJ (2012). Single nucleotide polymorphisms in ghrelin gene and the resulting genetic variants at ghrelin locus in different strains of indigenous Tswana chickens. African Journal of Biotechnology, 11: 10534-10540. DOI: https://www.doi.org/10.5897/AJB11.2139 ISSN 1684-5315

Lachance J (2008). A fundamental relationship between genotype frequencies and fitnesses. Genetics, 180: 10871093. DOI: https://www.doi.org/10.1534/genetics.108.093518

Lamolle G, Mónica Marin M, and Alvarez-Valin F (2006). Silent mutations in the gene encoding the p53 protein are preferentially located in conserved amino acid positions and splicing enhancers. Mutation Research, 600: 102-12. DOI: https://doi.org/10.1016/j.mrfmmm.2006.03.004

Mazzi CM, Ferro JA, Ferro MIT, Savino VJM, Coelho AAD, and Macari M (2003). Polymorphism analysis of the hsp70 stress gene in broiler chickens (Gallus gallus) of different breeds. Genetics and Molecular Biology, 26: 275-281. DOI: https://www.doi.org/10.1590/S1415-47572003000300010

Melesse A, Maak S, Schmidt R., and von Lengerken G (2011). Effect of long-term heat stress on some performance traits and plasma enzyme activities in naked-neck chickens and their F1 crosses with commercial layer breeds. Livestock Science, 141: 227-231. DOI: http://dx.doi.org/10.1016/j.livsci.2011.06.007.

Morimoto RI, Clayton S, Hunt OT, Shu-Ying Huang O, Berg K L, and BanerjilI SS (1986). Organization, nucleotide sequence, and transcription of the chicken HSP-70 gene. The Journal of Biological Chemistry, 261: 12692-12699. Available at: https://www.jbc.org/article/S0021$\underline{9258(18) 67147-9 / p d f}$

Najafi M, Rouhi MA, Mokhtari R, and Kazemi H (2018). Genetic analysis of a novel polymorphism in coding region of HSP70 gene and its association with some productive and its reproductive traits in Mazandaran native breeder hens. Journal of Genetic Disorders and Genetic Medicine, 2: 1-5. Available at: https://www.pulsus.com/scholarlyarticles/genetic-analysis-of-a-novel-polymorphism-incoding-region-of-hsp70-gene-and-its-association-withsome-productive-and-rep.pdf

Negri A, Oliveri C, Sforzini S, Mignione F, Viarengo A, and Banni M (2013). Transcriptional response of the mussel Mytilus galloprovincialis (Lam) following exposure to heat stress and copper. Plos One, 8: e66802. DOI: https://www.doi.org/10.1371/journal.pone.0066802

Oberheitmann A (2013). Some remarks on the individual contribution to climate change. American Journal of
Climate Change, 2: 198-202. DOI: http://www.dx.doi.org/10.4236/ajcc.2013.23020

Öner Y, Keskin A, Üstüner H, Soysa D, and Karakaş V (2017). Genetic diversity of the 3 ' and 5 ' untranslated regions of the HSP70.1 gene between native Turkish and Holstein Friesian cattle breeds. South African Journal of Animal Science, 47: 424-439. DOI: https://www.doi.org/10.4314/sajas.v47i4.2

Qiagen (2003). DNeasy tissue handbook. Protocol for isolation of genomic DNA from whole nucleated or non-nucleated animal blood. Valencia, California, USA, p. 30. Available at: http://www.bea.ki.se/documents/EN-DNeasy\%20handbook.pdf

Raymond M, and Rousset F (1995). GENEPOP (version 1.2): Population genetics software for exact tests and ecumenicism. Journal of Heredity, 86: 248-249. DOI: https://www.doi.org/10.1093/oxfordjournals.jhered.a111573

Silver JT, and Noble EG (2011). Regulation of survival gene hsp70. Cell Stress Chaperones, 17: 1-9. DOI: https://www.doi.org/10.1007/s12192-011-0290-6

Simmonds P (2012). SSE: A nucleotide and amino acid sequence analysis platform. BMC Research Notes, 5: 50. DOI: https://www.doi.org/10.1186/1756-0500-5-50

Sodhi M, Mukesh M, Kishore A, Mishra BP, Katana RS, and Joshi BK (2013). Novel polymorphisms in UTR and coding region of inducible heat shock protein 70.1 gene in tropically adapted Indian zebu cattle and riverine buffalo. Gene, 527: 606-615. DOI: https://www.doi.org/10.1016/j.gene.2013.05.078

Tamura K, Dudley J, Nei M, and Kumar S (2007). MEGA4: Molecular Evolutionary Genetics Analysis (MEGA) software version 4.0. Molecular Biology and Evolution, 24: 1596-1599. https://www.doi.org/10.1093/molbev/msm092

Tamzil MH (2014). Stres panas pada unggas: Metabolisme, akibat dan upaya penanggulangannya. Wartazoa, 24: 57-66. DOI: http://dx.doi.org/10.14334/wartazoa.v24i2.1049

Vallone PM, Hill CR, and Butler JM (2008). Demonstration of rapid multiplex PCR amplification involving 16 genetic loci. Genetics, 3(1): 42-45. DOI: https://www.doi.org/10.1016/j.fsigen.2008.09.005

Vignal A, Milan D, Cristobal MS, and Eggen A (2002). A review on SNP and other types of molecular markers and their use in animal genetics. Genetics Selection Evolution, 34: 275. Available https://gsejournal.biomedcentral.com/articles/10.1186/12979686-34-3-275

Zhao P, Javed S, Shi X, Wu B, Zhang D, Xu S, and Wang X (2020). Varying architecture of heat shock elements contributes to distinct magnitudes of target gene expression and diverged biological pathways in heat stress response of bread wheat. Frontiers in Genetics, 11: 1-6. DOI: https://www.doi.org/10.3389/fgene.2020.00030

Zuiderweg ER, Bertelsen EB, Rousaki A, Maye MP, Gestwicki JE, and Ahmad A (2013). Allostery in the Hsp70 chaperone proteins, Topics in Current Chemistry, 328: 99-153. DOI: https://www.doi.org/10.1007/128_2012_323 